Check for updates

Cite this: RSC Adv., 2018, 8, 10634

Received 22nd January 2018

Accepted 28th February 2018

DOI: $10.1039 / c 8 r a 00636 a$

rsc.li/rsc-advances

\section{Molecular modeling studies and in vitro screening of dihydrorugosaflavonoid and its derivatives against Mycobacterium tuberculosis $\uparrow$}

\author{
Ninad V. Puranik, (D) ac Pratibha Srivastava, (iD *ac Sagar Swami, (D) ${ }^{\mathrm{b}}$ Amit Choudhari (D) ${ }^{\mathrm{b}}$ \\ and Dhiman Sarkar (D) ${ }^{\text {b }}$
}

Novel drug regimens against tuberculosis (TB) are urgently needed and may be developed by targeting essential enzymes of Mtb that sustain the pathogenicity of tuberculosis. In the present investigation, series of compounds ( $5 a-f$ and $6 a-f$ ) based on a naturally occurring rugosaflavonoid moiety were evaluated by in silico molecular modeling studies against $\beta$-ketoacyl-ACP reductase (MabA) (PDB ID: IUZN) and pantothenate kinase (PanK) (PDB ID: 3AF3). Compounds 5a, 5c, 5d, and 6c, which had docking scores of $-8.29,-8.36,-8.17$ and $-7.39 \mathrm{kcal} \mathrm{mol}^{-1}$, respectively, displayed interactions with MabA that were better than those of isoniazid $\left(-6.81 \mathrm{kcal} \mathrm{mol}^{-1}\right)$. Similarly, compounds $5 \mathrm{a}, 5 \mathrm{c}, 5 \mathrm{~d}$, and $6 \mathrm{c}$, which had docking scores of $-7.55,-7.64,-7.40$ and $-6.7 \mathrm{kcal} \mathrm{mol}^{-1}$, respectively, displayed interactions with PanK that were comparable to those of isoniazid $\left(-7.64 \mathrm{kcal} \mathrm{mol}^{-1}\right)$. Because of their docking scores, these compounds were screened in vitro against Mycobacterium tuberculosis H37Ra (Mtb) using an XRMA protocol. Among the screened compounds, the dihydrorugosaflavonoid derivatives $5 \mathrm{a}, 5 \mathrm{c}$, and $5 \mathrm{~d}$ had $\mathrm{IC}_{50}$ values of $12.93,8.43$ and $11.3 \mu \mathrm{g} \mathrm{mL} \mathrm{L}^{-1}$, respectively, and exhibited better inhibitory activity than the parent rugosaflavonoid derivatives. The rugosaflavonoid derivative $6 \mathrm{c}$ had an $\mathrm{IC}_{50}$ value of $17.57 \mu \mathrm{g} \mathrm{mL}{ }^{-1}$. The synthesized compounds also displayed inhibitory activity against the Gram-positive bacteria Bacillus subtilis and Staphylococcus aureus. The present study will be helpful for the further development of these molecules into antitubercular lead candidates.

\section{Introduction}

Mycobacterium tuberculosis (Mtb) is the causative agent of tuberculosis (TB), which affected approximately 10.4 million people in 2015. ${ }^{\mathbf{1}}$ The World Health Organization (WHO) introduced the DOTS (Directly Observed Treatment, Short Course) strategy, which has proven successful in effectively achieving treatment rates of higher than $90 \%$. However, the prolonged duration (6-9 months) of the DOTS strategy and spontaneous gene mutations in pathogenic strains have led to resistance to the drugs. ${ }^{2}$ Hence, the emergence of cases of multi-drug resistance (MDR) and extensive drug resistance (XDR) have increased in recent years. To overcome the problems associated with this pandemic, there is an urgent need to develop effective strategies for treating and controlling TB. One strategy would comprise targeting essential enzymes of Mtb that are relevant to

\footnotetext{
${ }^{a}$ Bioprospecting Group, Agharkar Research Institute, G. G. Agarkar Road, Pune 411004, Maharashtra, India.E-mail: ninadv_puranik@yahoo.co.in; psrivastava@aripune.org ${ }^{b}$ Organic Chemistry Division, National Chemical Laboratory, Dr Homi Bhabha Road, Pune-411008, Maharashtra, India.E-mail: d.sarkar@ncl.res.in ${ }^{c}$ Savitribai Phule Pune University, Pune-411007, India

$\dagger$ Electronic supplementary information (ESI) available. See DOI: 10.1039/c8ra00636a
}

its survival and growth within the host cell. In this context, enzymes that participate in biosynthetic pathways represent attractive targets for the discovery of novel anti-tuberculosis agents. Among these, $\beta$-ketoacyl-ACP synthase (KAS) and pantothenate kinase (PanK) are two target enzymes that play important roles in the fatty acid synthesis (FASII) system and the biosynthetic pathway of coenzyme A (CoA), respectively. ${ }^{3,4} \beta$ Ketoacyl-ACP reductase (MabA) comprises a complex group of enzymes responsible for the production of very-long-chain fatty acid derivatives that are the chief precursors of mycolic acids, which are the main constituents of the M. tuberculosis cell wall. Pantothenate kinase (PanK), on the other hand, catalyzes the ATP-dependent phosphorylation of pantothenate, which is the initial step in the universal biosynthetic pathway of coenzyme A (CoA) from pantothenic acid. ${ }^{5-8}$ Rugosaflavonoid is a naturally occurring flavonoid isolated by $\mathrm{Hu}$ et al. ${ }^{9}$ from the flower buds of the plant Rosa rugosa. In our ongoing research to develop simple and cost-effective synthetic methodologies for naturally occurring chromones, we have reported the first total synthesis of rugosaflavonoid and its derivatives and identified their cytotoxic potential towards breast cancer cells. ${ }^{10}$ Recently, Villaume et $a .^{11}$ performed structure-activity relationship (SAR) studies and identified mandatory sites that are necessary for a flavone molecule to exhibit anti-TB activity. As the molecules 


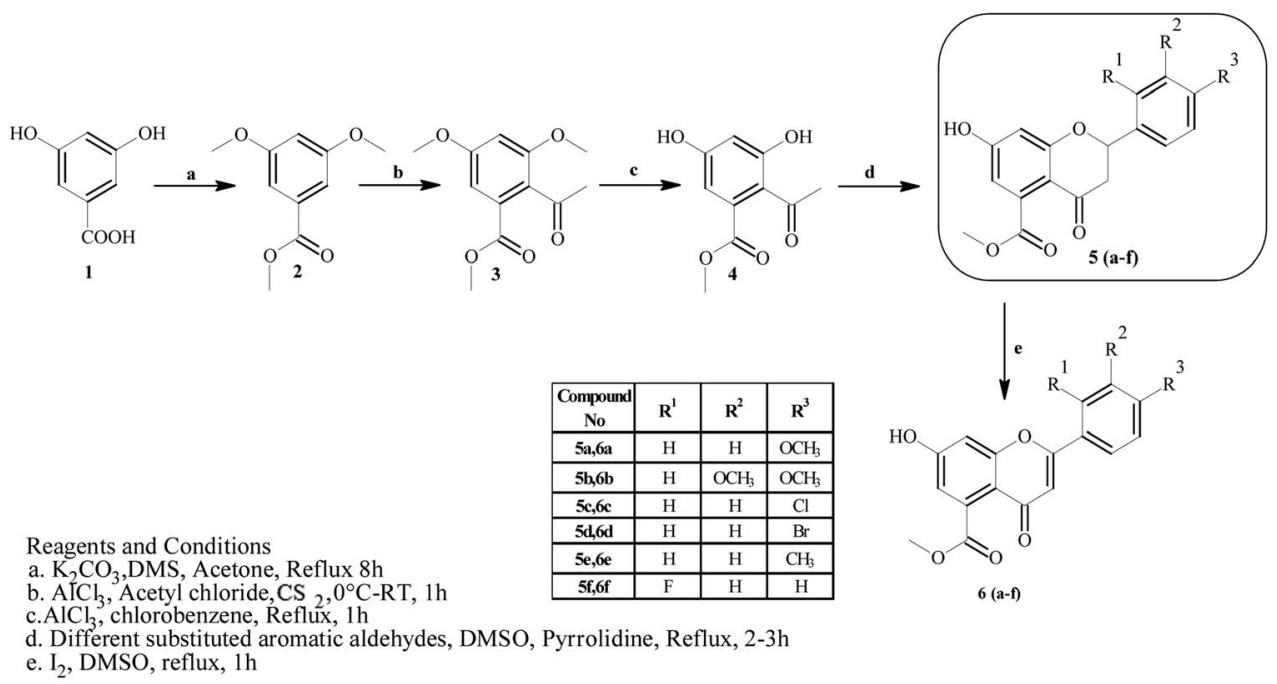

Scheme 1 Synthesis of rugosaflavonoid and its derivatives.

synthesized in the present study (Scheme 1) possess the same backbone, this encouraged us to perform molecular docking studies of the active sites of $\beta$-ketoacyl-ACP reductase (MabA) (PDB ID: IUZN) and pantothenate kinase (PanK) (PDB ID: 3AF3). The results for interactions obtained by these docking studies stimulated us to carry out further in vitro antitubercular screening of derivatives against M. tuberculosis H37Ra (Mtb).

\section{Results and discussion}

\subsection{In silico studies}

2.1.1 Molecular docking. Molecular docking studies were performed to understand the binding probability of the designed molecules. The docking studies showed that compounds $\mathbf{5 a}, \mathbf{5 c}, \mathbf{5 d}$ and $\mathbf{6 c}$ docked with the active pockets of 1UZN ( $\beta$-ketoacyl-ACP reductase) and 3AF3 (pantothenate kinase) and interacted with the active amino acids. Compounds $\mathbf{5}(\mathbf{a}-\mathbf{f})$ and $\mathbf{6}(\mathbf{a}-\mathbf{f})$ were surrounded in the active pocket of $1 \mathrm{UZN}$ by Gly22, Asn24, Arg25, Gly26, Ile27, Gly28, Asn88, Ala89, Gly90, Ile138, Gly139, Ser140, Pro183, Gly184, Tyr185, Ile186, Thr188, Met190, and Thr191. Compounds 5a, 5c, 5d and $\mathbf{6 c}$ displayed non-bonding interactions with Gly139, Ser140, and Ile186. MabA (1UZN) contains the amino acids Ser140, Tyr153, and Lys157, which are linked to form the catalytic triad of MabA. Any mutation in the Ser140 residue results in the complete loss of enzymatic activity. Therefore, the interaction of inhibitors with Ser140 may be considered to be important for inhibition. The amino acid Gly90 has been shown to be involved in the complexation of MabA with its natural cofactor NADPH, whereas any mutation of Gly139 to Ala139 causes complete inactivation of the protein by freezing the catalytic triad into a closed form. ${ }^{12}$ All the active compounds were in close proximity of the active triad and established interactions with Ser140 and Gly139, as depicted in Fig. 1.

\section{5a with 1UZN}

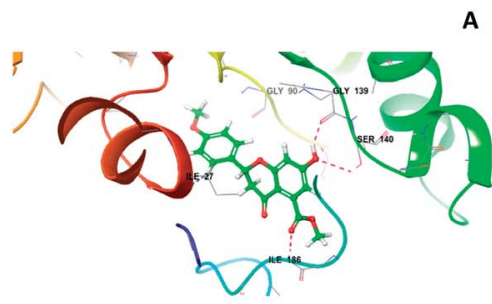

$6 c$ with $1 U Z N$

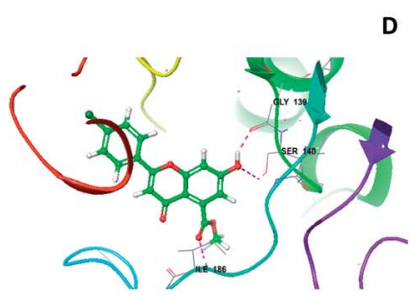

A
$5 c$ with 1UZN

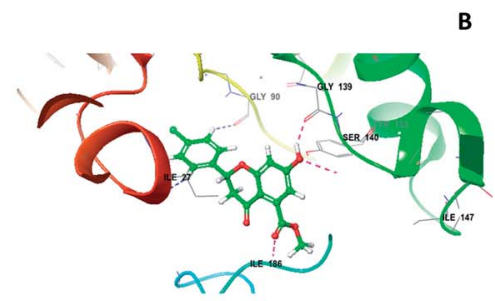

Quercetin with1UZN

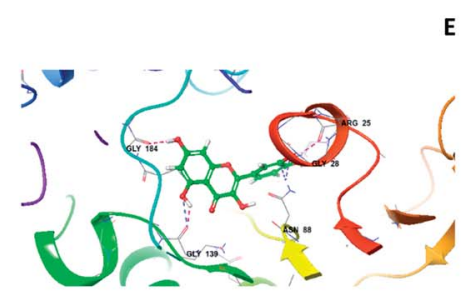

B

E 5d with 1UZN

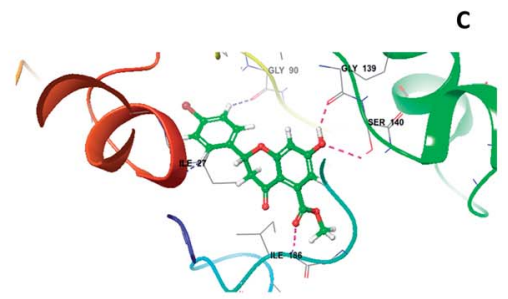

Isoniazid with 1UZN

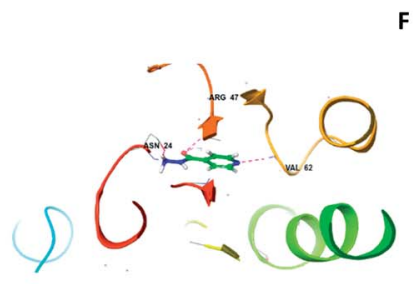

Fig. 1 Interactions of $5 a, 5 c, 5 d, 6 c$, quercetin, and isoniazid with $\beta$-ketoacyl-ACP reductase (MabA) (PDB code 1UZN). 
5a with 3 AF3

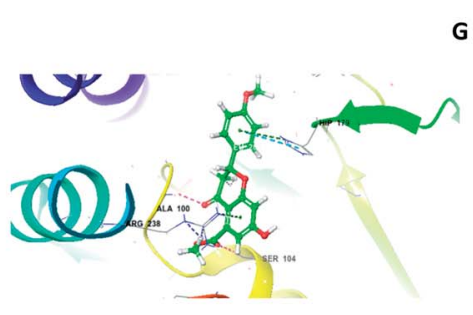

$6 c$ with 3AF3

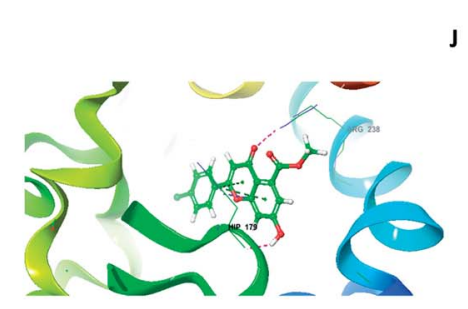

G 5c with $3 A F 3$

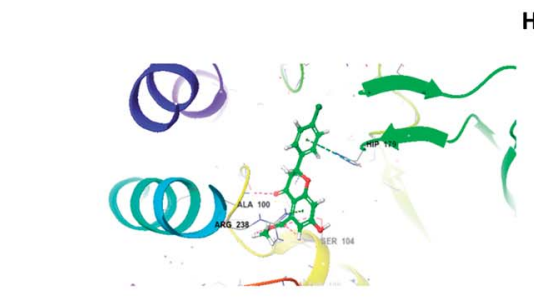

Querecetin with 3AF3

K

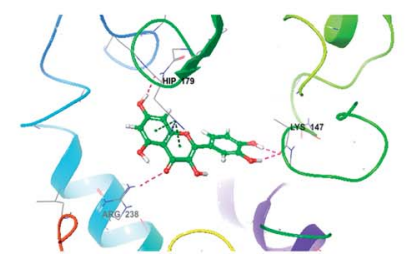

$5 d$ with $3 A F 3$

H

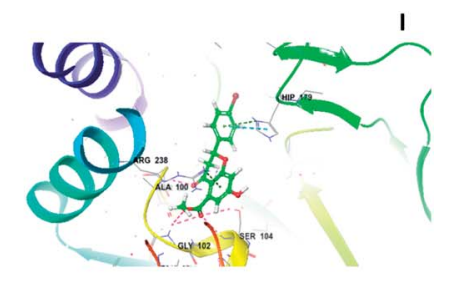

Isoniazid with 3AF3

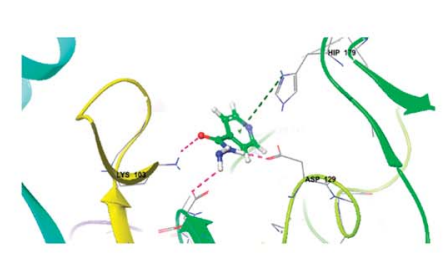

Fig. 2 Molecular interactions of 5a, 5c, 5d, 6c, quercetin and isoniazid with pantothenate kinase (PanK) (PDB code 3AF3).

The docking scores of $\mathbf{5 a}, \mathbf{5 c}, \mathbf{5 d}$, and $\mathbf{6 c}$ with 1 UZN were found to be $-8.296,-8.366,-8.175$ and $-7.398 \mathrm{kcal} \mathrm{mol}^{-1}$, respectively. The standard compound isoniazid bound in a different manner to Asn24, Arg47 and Val62 with a score of $-6.813 \mathrm{kcal} \mathrm{mol}^{-1}$. Besides, we performed docking studies of quercetin, which is a ligand very well known for its biological potential. We found that quercetin interacted with Arg25, Gly28, Asn88, Gly139, and Gly184 with a docking score of $-9.412 \mathrm{kcal} \mathrm{mol}^{-1}$.

The central beta-sheet and p-loop are highly conserved in all pantothenate kinase enzymes (PanK). Differences can be seen in the surrounding loops and helix. The residues Tyr235 and Asn277 are involved in binding with pantothenate and phosphopantothenate. ${ }^{13}$ The active site pocket includes residues such as Hip179, Arg238, Tyr182, and Tyr177. ${ }^{14}$ During the molecular docking of $\mathbf{5}(\mathbf{a}-\mathbf{f})$ and $\mathbf{6}(\mathbf{a}-\mathbf{f})$ with PanK (PDB code: 3AF3), compounds 5a, 5c, 5d, and $\mathbf{6 c}$ displayed interactions with Ala100, Gly102, Ser104, Hip179 and Arg238 (Fig. 2).
Isoniazid interacted with Lys103, Asp129, Hip179 and Glu201. The docking scores were found to be comparable to that of isoniazid (Table 1). Quercetin interacted with Lys147, Hip179 and Arg238. Another form of PanK (PDB 4BFZ) also displayed similar kinds of interactions with these compounds in the active binding pocket (data not presented).

2.1.2 Physicochemical properties and ADME predictions. An in silico prediction of physically significant and pharmaceutically relevant properties of the molecules was performed using QikProp. The data are presented in Table 2.

\subsection{Biological screening}

2.2.1 Antitubercular activity. Because of the encouraging results of binding with $\beta$-ketoacyl-ACP reductase and pantothenate kinase, the synthesized compounds (5a-5f and $\mathbf{6 a - 6 f}$ ) were subsequently screened for their in vitro antitubercular activity against $M$. tuberculosis H37Ra using an established XTT reduction menadione assay (XRMA). Table 3 summarises the

Table 1 Docking scores and residues of $1 \mathrm{UZN}$ and $3 A F 3$ interacting with $5 a-f$ and $6 a-f$

\begin{tabular}{|c|c|c|c|c|}
\hline S. No. & $1 \mathrm{UZN}$ & $\begin{array}{l}\text { Docking score } \\
\text { with } 1 \mathrm{UZN}\end{array}$ & 3AF3 & $\begin{array}{l}\text { Docking score } \\
\text { with } 3 \mathrm{AF} 3\end{array}$ \\
\hline $5 \mathbf{a}$ & Gly139, Ser140, Ile186 & -8.296 & Ala100, Ser104, Hip179, Arg238 & -7.553 \\
\hline $5 \mathbf{b}$ & Gly139, Ser140, Ile186 & -6.12 & Ala100, Ser104, Hip179, Arg238 & -6.83 \\
\hline $5 c$ & Gly139, Ser140, Ile186 & -8.366 & Ala100, Gly102, Ser104, Hip179, Arg238 & -7.64 \\
\hline $5 d$ & Gly139, Ser140, Ile186 & -8.175 & Ala100, Gly102, Ser104, Hip179, Arg238 & -7.40 \\
\hline $5 e$ & Ser140, Tyr153, Ile186, Thr191 & -6.312 & Ala100, Gly102, Ser104, Hip179, Arg238 & -7.13 \\
\hline $5 \mathbf{f}$ & Gly139, Ser140, Ile186 & -7.913 & Ala100, Gly102, Ser104, Hip179, Arg238 & -7.34 \\
\hline $6 \mathbf{a}$ & Asn88, Gln150, Ile186, Thr191 & -6.334 & Ala100, Gly102, Ser104, Arg108, Hip179 & -6.052 \\
\hline $6 \mathbf{b}$ & Ile27, Gly90 & -6.500 & Ala100, Ser104, Hip179, Arg238 & -5.302 \\
\hline $6 c$ & Ile27, Asn88, Lys157 & -7.398 & Ser98, Gly102, Lys103, Hip179 & -6.72 \\
\hline 6d & Ser140, Tyr153, Thr191 & -6.901 & Lys103, Ser104, Hip179, Arg238 & -5.533 \\
\hline $6 e$ & Ile27, Gly90 & -6.101 & Ala11, Ser104 & -5.897 \\
\hline $6 f$ & Gly139, Ser140, Ile186 & -6.788 & Ala100, Gly102, Ser104, Hip179, Arg238 & -6.675 \\
\hline Quercetin & Arg25, Gly28, Asn88, Gly139, Gly184 & -9.412 & Lys147, Hip179, Arg238 & -7.882 \\
\hline Isoniazid & Asn24, Arg47, Val62 & -6.813 & Lys103, Asp129, Hip179, Glu201 & -7.642 \\
\hline
\end{tabular}




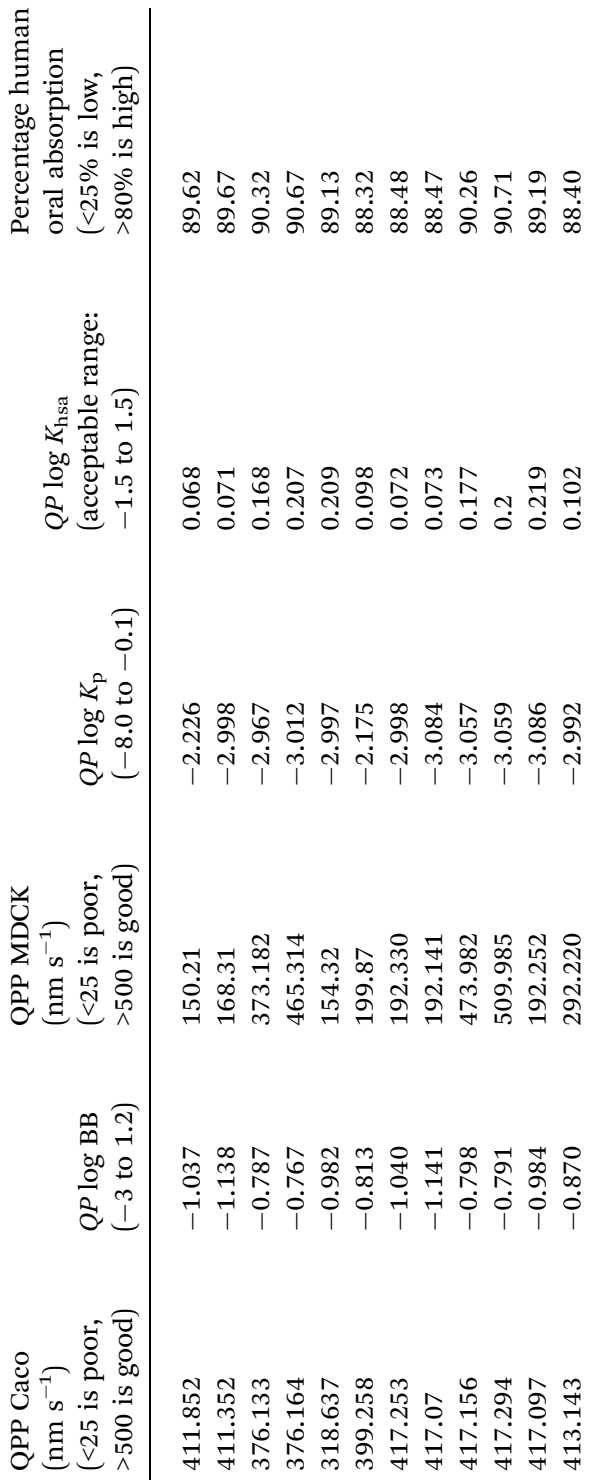

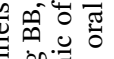
등응

$\because-\overline{0}$ 舟 ' 赵융 范范范 능 它声

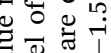

$\mathrm{IC}_{50}$ and MIC values of all the compounds. Among the derivatives that were screened, compounds $\mathbf{5 c}, \mathbf{5 a}$, and $\mathbf{5 d}$ had $\mathbf{I C}_{50}$ values of $8.43,12.93$ and $11.3 \mu \mathrm{g} \mathrm{mL} \mathrm{L}^{-1}$, respectively, whereas compound $6 \mathrm{c}$ had an $\mathrm{IC}_{50}$ value in the range of $17.57 \mu \mathrm{g} \mathrm{mL} \mathrm{m}^{-1}$. All the remaining compounds exhibited $\mathrm{IC}_{50}$ values corresponding to a concentration of $>20 \mu \mathrm{g} \mathrm{mL} \mathrm{m}^{-1}$.

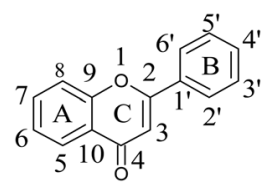

2.2.2 Basic backbone of flavone scaffold and its nomenclature. Flavone moieties contain three rings named as A, B and $\mathrm{C}$. The synthesized compounds mostly have variations in ring B. The screening results for the dihydro derivatives showed variations in percentage inhibition with changes in the substituents on ring B. Amongst the tested compounds, compound 5a, which has a methoxy substituent at the $4^{\prime}$ position, displayed $50 \%$ inhibition at $12.93 \mu \mathrm{g} \mathrm{mL} \mathrm{m}^{-1}$ and $90 \%$ inhibition at $>30 \mu \mathrm{g} \mathrm{mL} \mathrm{m}^{-1}$. The addition of another methoxy group at the $3^{\prime}$ position of ring B (5b) resulted in a sharp decrease in activity. The replacement of the methoxy group by a halogen atom (5c and $\mathbf{5 d}$ ) enhanced the inhibition, and $\mathbf{5 c}$ and $5 \mathrm{~d}$ exhibited $50 \%$ inhibition at $8.43 \mu \mathrm{g} \mathrm{mL} \mathrm{m}^{-1}$ and $11.3 \mu \mathrm{g}$ $\mathrm{mL}^{-1}$, respectively. The derivative with a methyl group at the $4^{\prime}$ position of ring B (5e) displayed moderate activity (Table 3). Rugosaflavonoid and its derivatives (6a-f) (double bond at $\mathrm{C} 2=\mathrm{C} 3$ ) did not exhibit any inhibition except for $\mathbf{6 c}$, which exhibited $90 \%$ inhibition at $28.90 \mu \mathrm{g} \mathrm{mL}{ }^{-1}$. Villaume et al. ${ }^{11}$ also reported the importance of ring B when they screened naturally occurring flavones as UGM inhibitors. They observed a total loss of activity after the removal of ring B. In our case, with variations in ring B we observed declines and increases in inhibitory activity. On comparing the dihydrorugosaflavonoid derivatives with the naturally occurring molecule quercetin, we found that our compounds exhibited better inhibition than quercetin. These results indicate that dihydro derivatives of rugosaflavonoid are much better antitubercular agents than the flavone moiety of rugosaflavonoid. Besides, the results of an antibacterial assay showed that $\mathbf{5 c}$ and $\mathbf{5 d}$ displayed very good antibacterial activity against $B$. subtilis, with $\mathrm{IC}_{50}$ values of $6.25 \mu \mathrm{g} \mathrm{mL}{ }^{-1}$ and $7.24 \mu \mathrm{g} \mathrm{mL} L^{-1}$, respectively. When tested against $S$. aureus, 5c, 5d, 6c, 6d and $\mathbf{6 f}$ displayed excellent activity, with $\mathrm{IC}_{50}$ values of $2.77 \mu \mathrm{g} \mathrm{mL}^{-1}, 5.63 \mu \mathrm{g} \mathrm{mL} \mathrm{m}^{-1}, 6.45 \mu \mathrm{g}$ $\mathrm{mL}^{-1}, 8.16 \mu \mathrm{g} \mathrm{mL}^{-1}$ and $2.96 \mu \mathrm{g} \mathrm{mL}^{-1}$, respectively (Table 4). The compounds with good antibacterial activity were further tested to determine their minimum inhibitory concentration (MIC) using a dose-response curve. Compound 5c exhibited MIC values of $27.34 \mu \mathrm{g} \mathrm{mL}^{-1}$ and $20.44 \mu \mathrm{g} \mathrm{mL}^{-1}$ against $B$. subtilis and $S$. aureus, respectively. Moreover, 5d and $6 \mathbf{c}$ exhibited MIC values of $25.02 \mu \mathrm{g} \mathrm{mL} L^{-1}$ and $27.53 \mu \mathrm{g} \mathrm{mL} \mathrm{m}^{-1}$, respectively, against $S$. aureus (Table 4 ). All the compounds (5a5f and 6a-6f) exhibited $\mathrm{IC}_{50}$ and MIC values of $>30 \mu \mathrm{g} \mathrm{mL}$ against the Gram-negative strains E. coli and P. aeruginosa (Table 4). The results of the in vitro screening of these compounds against Gram-positive and Gram-negative bacteria 
Table 3 Results for in vitro antitubercular activity of $5 a-f$ and $6 a-f$ against Mtb H37Ra

\begin{tabular}{|c|c|c|c|c|c|c|c|c|c|}
\hline Sr. no. & Structure & M. W. & $\begin{array}{l}\mathrm{IC}_{50} \\
\mu \mathrm{g} \mathrm{mL}^{-1}\end{array}$ & $\begin{array}{l}\mathrm{MIC}_{90} \\
\mu \mathrm{g} \mathrm{mL}^{-1}\end{array}$ & Sr. no. & Structure & M. W. & $\begin{array}{l}\mathrm{IC}_{50} \\
\mu \mathrm{g} \mathrm{mL}^{-1}\end{array}$ & $\begin{array}{l}\mathrm{MIC}_{90} \\
\mu \mathrm{g} \mathrm{mL}^{-1}\end{array}$ \\
\hline
\end{tabular}

$5 a$<smiles>COC(=O)c1cc(O)cc2c1C(=O)CC(c1ccc(OC)cc1)O2</smiles>

$328.31 \quad 12.93 \quad>30$<smiles>COC(=O)c1cc(O)cc2c1C(=O)CC(c1ccc(OC)c(OC)c1)O2</smiles>

$358.34>30$

$>30$

$332.73 \quad 8.43$

27.26

377.18

11.3

312.31

25.21

$>30$

$316.28>30$
$6 a$<smiles>COC(=O)c1cc(O)cc2oc(-c3ccc(OC)cc3)cc(=O)c12</smiles>

326.30

$>30$

$>30$

$6 b$<smiles>COC(=O)c1cc(O)cc2oc(-c3ccc(OC)c(OC)c3)cc(=O)c12</smiles>

$356.32>30$

$>30$

$6 c$<smiles>COC(=O)c1cc(O)cc2oc(-c3ccc(C)cc3)cc(=O)c12</smiles>

$330.71 \quad 17.57$

28.90

6d<smiles>COC(=O)c1cc(O)cc2oc(-c3ccc(Br)cc3)cc(=O)c12</smiles>

375.17

$>30$

$>30$

$6 e$<smiles>COC(=O)c1cc(O)cc2oc(-c3ccc(C)cc3)cc(=O)c12</smiles>

310.30

$>30$

$6 f$
$314.26>30$

$>30$ demonstrated that the synthesized compounds are more active against the Gram-positive bacteria $B$. subtilis and $S$. aureus (Table 4). Finally, these results indicate that the dihydro derivatives of rugosaflavonoid are much better antitubercular agents than the flavone moiety of rugosaflavonoid and are also capable of inhibiting the growth of Gram-positive bacteria.

\section{Conclusions}

In the present study, we docked and synthesized dihydrorugosaflavonoid and rugosaflavonoid derivatives. The derivatives were evaluated in silico against Mtb $\beta$-ketoacyl-ACP reductase (MabA)
(PDB ID: 1UZN) and PanK (PDB ID: 3AF3), and their activity was confirmed in vitro in $M$. tuberculosis $\mathrm{H} 37 \mathrm{Ra}$. The results of this integrated effort explicitly support the efficacy of the dihydrorugosaflavonoid derivatives in inhibiting MTB, which opens new avenues for the further development of these molecules into antitubercular lead candidates.

\section{Materials and methods}

\subsection{General methods}

All the chemicals used during the reactions were procured from Spectrochem, India. ${ }^{1} \mathrm{H}$ NMR and ${ }^{13} \mathrm{C}$ NMR spectra were 
Table 4 In vitro antibacterial activity of the synthesized derivatives (5a-6f) against E. coli, $P$. aeruginosa, S. aureus and B. subtilis

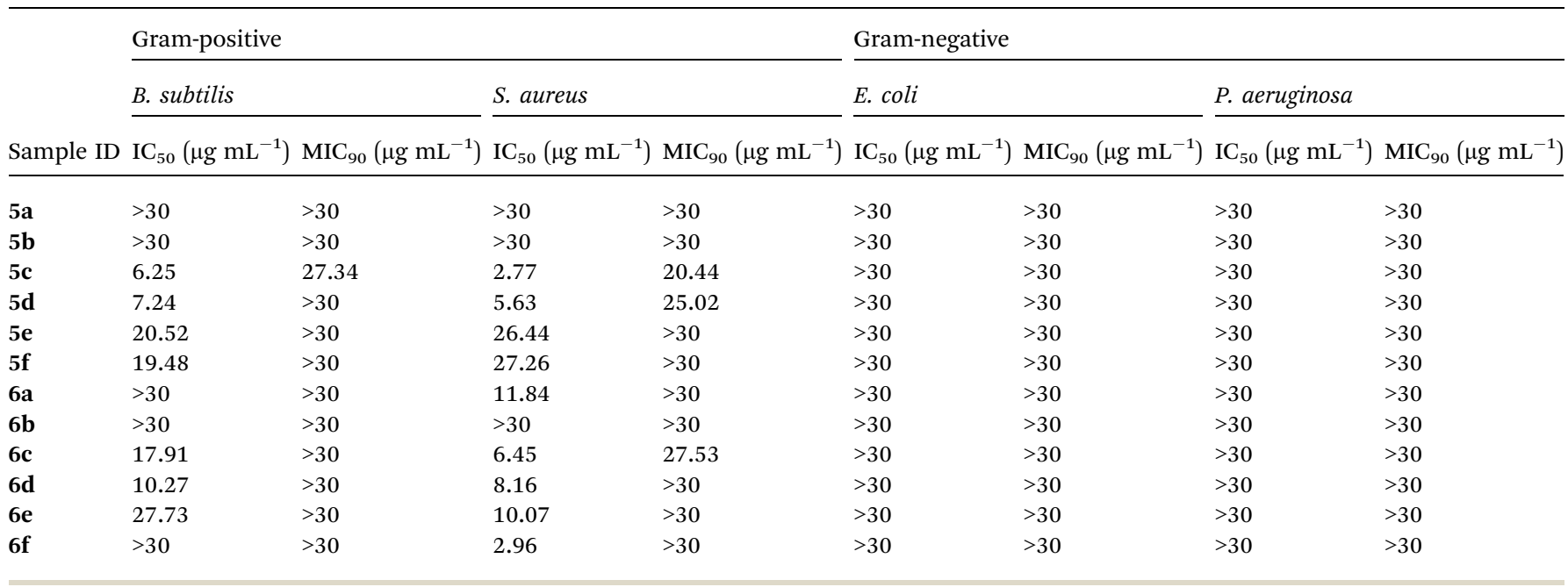

recorded at room temperature using a Varian spectrometer at $400 \mathrm{MHz}$ and $100 \mathrm{MHz}$, respectively. Chemical shift values are reported with reference to TMS as an internal standard. The samples were prepared by dissolving the synthesized compounds in DMSO- $\mathrm{d}_{6}$, and chemical shifts are expressed in $\delta(\mathrm{ppm})$ and coupling constants $(J)$ in $\mathrm{Hz}$. The abbreviations for the splitting patterns are as follows: s, singlet; d, doublet; t, triplet; q, quartet; m, unresolved multiplet; dd, doublet of doublets. Column chromatography was performed on Merck silica gel 60 (230-400 mesh). Analytical thin-layer chromatography was carried out on pre-coated Merck silica gel $60 \mathrm{~F}_{254}$, and iodine was used as the developing reagent. IR spectra were recorded with a Shimadzu FTIR IR Affinity-1 spectrophotometer. CHNS analysis was performed using an Elementar Vario EL III analyzer.

\subsection{Molecular docking}

The 3D structures of MabA (PDB code: 1UZN) and PanK (PDB code: $3 \mathrm{AF} 3$ and $4 \mathrm{BFZ}$ ) were chosen as ideal target proteins for docking with dihydrorugosaflavonoid and rugosaflavonoid derivatives. Naturally occurring quercetin and isoniazid were employed as standard ligands.

\subsubsection{Protein preparation}

The selected PDB files of MabA (PDB Code: 1UZN) and PanK (PDB code: 3AF3 and 4BFZ) used for docking studies were downloaded from the RCSB site (www.rcsb.org) and pre-treated prior to the docking calculations with the help of the Protein Preparation Wizard of the Maestro 11.2 program from Schrödinger. Guidelines for the use of the Protein Preparation Wizard were received from a Maestro online tutorial. These steps were followed: (i) addition of hydrogen atoms to the protein structures; (ii) assignment of bond orders; (iii) removal of crystallographic waters; (iv) regeneration of states; (v) optimization of hydrogen bonds using the PROPKA program from Schrödinger before restrained minimization using the OPLS force field; and (vi) setting the convergence of heavy atoms at the RMSD of $0.3 \AA$.

\subsubsection{Ligand preparation}

The dihydrorugosaflavonoid (5a-f) and rugosaflavonoid (6a-f) derivatives were selected as ligands. They were sketched using the 2D program (Ligand Preparation Wizard) of Maestro 11.2 and converted into a 3D model using the preset option. LigPrep accomplished several corrections of the ligands and provided low-energy structures with ring conformations. Energy minimization and optimization were performed using the Optimized Potential for Liquid Simulations (OPLS) force field. Subsequently, one conformation was generated for each ligand using Maestro 11.2 software from Schrödinger.

\subsubsection{Receptor grid generation}

Glide molecular docking software uses one ligand to interact with the X-ray crystal structure of the target protein for evaluation of the receptor grid for the active site. Receptor griddependent molecular docking helps ligands to bind in many possible conformations. Docking grids for both protein structures, namely, $1 \mathrm{UZN}$ and $3 \mathrm{AF} 3 / 4 \mathrm{BFZ}$ were created using the receptor grid generation option of Maestro. The grid box was positioned at the center of the cognate ligands of the protein structures complexed with their natural cofactor, and the maximum length of the docked ligands was fixed at $20 \AA$. The scaling factor and partial charge cut-off in van der Waals radius scaling were 0.25 and $1 \AA$, respectively. For other parameters such as sites, constraints, rotatable groups, and excluded volumes, the default settings of Maestro 11.2 were used.

\subsubsection{Glide molecular docking}

After the generation of the ligand and protein structures and the specification of the grid at the active site of the protein, molecular docking measurements were performed. The Glide molecular docking application uses efficient computational simulation techniques for the evaluation of particular poses 
and ligand flexibility, such as the Glide systematic method, which is a new approach for rapid, precise molecular docking, and the resulting GScore, which is an empirical scoring function that combines several parameters. The GScore is given in $\mathrm{kcal} \mathrm{mol}^{-1}$ and includes ligand-protein interaction energies, hydrophobic interactions, hydrogen bonds, internal energies, pi-pi stacking interactions, root mean square deviation (RMSD) and desolvation. The Glide module of the XP visualizer was used to analyze the specific ligand-protein interactions. The dihydrorugosaflavonoids, rugosaflavonoids, quercetin and the standard isoniazid were docked with the 3D structures of MabA and PanK with the help of Glide. The best-fit compounds for each target were identified by their optimal thermodynamic energy values, types of interactions, bonding potential, and conformations. ${ }^{15,16}$

\subsubsection{Studies of ADME properties}

The QikProp tool from Schrödinger (2017) was used to calculate, and provided information about, the absorption, distribution, metabolism, excretion, and toxicity (ADME/T) properties of the ligand molecules. It provided information such as $Q P \log P_{\mathrm{o}} / w$, $Q P \log \mathrm{BB}$, overall CNS activity, Caco-2 and MDCK cell permeability, $\log K_{\mathrm{hsa}}$ for binding to human serum albumin, percentage human oral absorption, etc. $^{17}$

\subsection{Chemistry}

4.3.1 Synthesis of methyl 3,5-dimethoxybenzoate (2). This was prepared as per the method reported by McNulty and Mcleod. ${ }^{18}$ In brief, 3,5-dihydroxybenzoic acid (6 mmol) in dry acetone was taken. To this mixture, $\mathrm{K}_{2} \mathrm{CO}_{3}(2.5 \mathrm{mmol})$ was added under stirring at $40{ }^{\circ} \mathrm{C}$ for $15 \mathrm{~min}$, and stirring was continued at $60{ }^{\circ} \mathrm{C}$ for $10 \mathrm{~min}$. Then, dimethyl sulfate $(2.2$ $\mathrm{mmol}$ ) was added dropwise over a period of $30 \mathrm{~min}$, and the temperature was increased slowly to $80^{\circ} \mathrm{C}$. The reaction mixture was allowed to reflux for $6 \mathrm{~h}$. The progress of the reaction was monitored by TLC. After completion, the reaction mixture was allowed to cool to room temperature and filtered through a celite bed. The filtered mixture was concentrated to obtain the crude product, which was slowly poured onto crushed ice with constant stirring to obtain a solid. The solid that was obtained was filtered and dried to give methyl 3,5-dimethoxybenzoate (2) in $91 \%$ yield.

4.3.2 Synthesis of methyl 2-acetyl-3,5-dimethoxybenzoate (3). Methyl 3,5-dimethoxybenzoate (2) (5 mmol) was mixed with acetyl chloride $(25 \mathrm{mmol})$ and carbon disulfide $(2 \mathrm{~mL})$ under dry $\mathrm{N}_{2}$ in an ice bath. ${ }^{19}$ To the reaction mixture $\mathrm{AlCl}_{3}(15$ $\mathrm{mmol}$ ) was added under vigorous stirring. The reaction was allowed to stir for $15 \mathrm{~min}$. The progress of the reaction was monitored by TLC. After completion, the reaction mixture was quenched with ice and extracted with ethyl acetate. The organic layer was separated, dried over sodium sulfate and concentrated to give the crude product, which was purified by column chromatography (hexane-ethyl acetate, $70: 30$ ) to obtain methyl 2acetyl-3,5-dimethoxybenzoate (3) in $52 \%$ yield.

4.3.3 Synthesis of methyl 2-acetyl-3,5-dihydroxybenzoate (4). Methyl 2-acetyl-3,5-dimethoxybenzoate (3) (4 mmol) was added to chlorobenzene, and $\mathrm{AlCl}_{3}(10 \mathrm{mmol})$ was added slowly at room temperature. ${ }^{20}$ The reaction mixture was heated to reflux for $1 \mathrm{~h}$. The progress of the reaction was monitored by TLC. After completion, the reaction mixture was cooled to room temperature and hydrolysed using $1 \mathrm{~N} \mathrm{HCl}$. The reaction mixture was extracted with ethyl acetate. The organic layer was separated, dried over sodium sulfate and concentrated to obtain the crude product, which was purified by column chromatography (hexane-ethyl acetate, $80: 20$ ) to give clean methyl 2acetyl-3,5-dihydroxybenzoate (4) in $68 \%$ yield.

4.3.4 General procedure for the synthesis of methyl 7hydroxy-2-(substituted phenyl)-4-oxo-3,4-dihydro-2H-chromene5-carboxylates (5a-f). Methyl 2-acetyl-3,5-dihydroxybenzoate (4) $(4.7 \mathrm{mmol})$ in DMSO was mixed with different substituted aromatic aldehydes $(4.7 \mathrm{mmol}), \mathrm{I}_{2}(0.23 \mathrm{mmol})$ and pyrrolidine $(2.3 \mathrm{mmol})$ as per the reported procedure, ${ }^{21}$ and the reaction mixture was allowed to reflux for $8 \mathrm{~h}$. The progress of the reaction was monitored by TLC. After completion, the mixture was cooled to room temperature and quenched with water. The aqueous layer was extracted with ethyl acetate. The organic layer was separated and washed with a brine solution. The organic layer was dried and concentrated to give the crude product, which was purified by column chromatography using hexane:ethyl acetate as the solvent system to obtain the products $\mathbf{5 a - f .}$

4.3.5 Methyl 7-hydroxy-2-(4-methoxyphenyl)-4-oxo-3,4dihydro-2H-chromene-5-carboxylate (5a). Yellow solid (48\%), $R_{\mathrm{f}}$ 0.46 (EtOAc/hexane, $3: 7)$; mp: $201{ }^{\circ} \mathrm{C}$; IR $\left(\mathrm{KBr}, \mathrm{cm}^{-1}\right): 3412$ $(\mathrm{OH}), 1707(\mathrm{C}=\mathrm{O}) ;{ }^{1} \mathrm{H}$ NMR (400 MHz, DMSO-d 6$): \delta 10.94(\mathrm{~s}, 1 \mathrm{H}$, $\mathrm{OH}), 7.44\left(\mathrm{~d}, J=8.4 \mathrm{~Hz}, 2 \mathrm{H}, 2^{\prime}-\mathrm{H}, 6^{\prime}-\mathrm{H}\right), 6.96(\mathrm{~d}, J=8.8 \mathrm{~Hz}, 2 \mathrm{H}$, $\left.3^{\prime}-\mathrm{H}, 5^{\prime}-\mathrm{H}\right), 6.42(\mathrm{~s}, 2 \mathrm{H}, 6-\mathrm{H}, 8-\mathrm{H}), 5.55(\mathrm{dd}, J=1.6,12 \mathrm{~Hz}, 1 \mathrm{H}, 2-$ $\mathrm{H}), 3.75\left(\mathrm{~s}, 3 \mathrm{H}, \mathrm{OCH}_{3}\right), 3.69\left(\mathrm{~s}, 3 \mathrm{H}, \mathrm{OCH}_{3}\right), 3.16(\mathrm{q}, J=3.2$, $13.2 \mathrm{~Hz}, 1 \mathrm{H}, 3-\mathrm{H}), 2.67$ (dd, $J=2.4,14.8 \mathrm{~Hz}, 1 \mathrm{H}, 3-\mathrm{H}$ ); ${ }^{13} \mathrm{C}$ NMR (100 MHz, DMSO-d ${ }_{6}$ ): $\delta 189.49,169.50,164.36,163.66,159.92$, 136.42, 131.76, 131.11, 128.73, 114.32, 110.82, 109.76, 107.64, 107.55, 79.19, 52.78, 52.46, 43.56; LCMS (ESI): $m / z$ calculated for $\mathrm{C}_{18} \mathrm{H}_{16} \mathrm{O}_{6}: 328.31$, found: 329.10 . Elemental analysis: calculated for $\mathrm{C}_{18} \mathrm{H}_{16} \mathrm{O}_{6}$ : C, 65.84, H, 4.90; found: $\mathrm{C}, 65.91, \mathrm{H}, 4.96$.

4.3.6 Methyl 2-(3,4-dimethoxyphenyl)-7-hydroxy-4-oxo-3,4dihydro-2H-chromene-5-carboxylate (5b). Yellow solid (41\%), $R_{\mathrm{f}}$ 0.5 (EtOAc/hexane, $3: 7)$; mp: $218{ }^{\circ} \mathrm{C}$; IR $\left(\mathrm{KBr}, \mathrm{cm}^{-1}\right): 3477(\mathrm{OH})$, $1732(\mathrm{C}=\mathrm{O}) ;{ }^{1} \mathrm{H}$ NMR (400 MHz, DMSO-d 6 ): $\delta 10.97(\mathrm{~s}, 1 \mathrm{H}, \mathrm{OH})$, $7.13\left(\mathrm{~s}, 1 \mathrm{H}, 2^{\prime}-\mathrm{H}\right), 7.03$ (d, $\left.J=8.0 \mathrm{~Hz}, 1 \mathrm{H}, 6^{\prime}-\mathrm{H}\right), 6.96$ (d, $J=$ $\left.8.0 \mathrm{~Hz}, 1 \mathrm{H}, 5^{\prime}-\mathrm{H}\right), 6.43(\mathrm{~s}, 2 \mathrm{H}, 6-\mathrm{H}, 8-\mathrm{H}), 5.52$ (dd, $J=2.8$, $12.8 \mathrm{~Hz}, 1 \mathrm{H}, 2-\mathrm{H}), 3.75\left(\mathrm{~s}, 9 \mathrm{H}, \mathrm{OCH}_{3}\right), 3.21$ (q, $J=4,13.2 \mathrm{~Hz}, 1 \mathrm{H}$, 3-H), 2.67 (dd, $J=2.8,14.4 \mathrm{~Hz}, 1 \mathrm{H}, 3-\mathrm{H}) ;{ }^{13} \mathrm{C}$ NMR $(100 \mathrm{MHz}$, DMSO-d $\left.{ }_{6}\right): \delta 189.53,169.50,164.36,163.64,149.51,149.18$, 136.40, 131.46, 119.79, 111.98, 111.09, 110.84, 109.78, 104.21, 79.51, 56.03, 56.03, 52.78, 43.66; LCMS (ESI): $m / z$ calculated for $\mathrm{C}_{19} \mathrm{H}_{18} \mathrm{O}_{7}: 358.34$, found: 359.10 . Elemental analysis: calculated for $\mathrm{C}_{19} \mathrm{H}_{18} \mathrm{O}_{7}$ : C, 63.67, $\mathrm{H}, 5.05$; found: $\mathrm{C}, 63.62, \mathrm{H}, 4.99$.

4.3.7 Methyl 2-(4-chlorophenyl)-7-hydroxy-4-oxo-3,4-dihydro-2H-chromene-5-carboxylate (5c). Yellow solid (40\%), $R_{\mathrm{f}} 0.68$ (EtOAc/hexane, $3: 7)$; mp: $198{ }^{\circ} \mathrm{C}$; IR $\left(\mathrm{KBr}, \mathrm{cm}^{-1}\right)$ : $3361(\mathrm{OH})$, $1735(\mathrm{C}=\mathrm{O}) ;{ }^{1} \mathrm{H}$ NMR (400 MHz, DMSO-d 6 ): $\delta 10.96(\mathrm{~s}, 1 \mathrm{H}, \mathrm{OH})$, $7.53\left(\mathrm{~d}, J=8.8 \mathrm{~Hz}, 2 \mathrm{H}, 3^{\prime}-\mathrm{H}, 5^{\prime}-\mathrm{H}\right), 7.46$ (d, $J=8.4 \mathrm{~Hz}, 2 \mathrm{H}, 2^{\prime}-\mathrm{H}$, $\left.6^{\prime}-\mathrm{H}\right), 6.44(\mathrm{~s}, 1 \mathrm{H}, 8-\mathrm{H}), 6.41(\mathrm{~s}, 1 \mathrm{H}, 6-\mathrm{H}), 5.63(\mathrm{dd}, J=3.2$, $12.8 \mathrm{~Hz}, 1 \mathrm{H}, 2-\mathrm{H}), 3.74\left(\mathrm{~s}, 3 \mathrm{H}, \mathrm{OCH}_{3}\right), 3.09$ (q, $J=4,12.8 \mathrm{~Hz}, 1 \mathrm{H}$, 
3-H), 2.72 (dd, $J=3.2,13.6 \mathrm{~Hz}, 1 \mathrm{H}, 3-\mathrm{H}) ;{ }^{13} \mathrm{C}$ NMR $(100 \mathrm{MHz}$, DMSO-d $\left.{ }_{6}\right): \delta 189.09,169.48,164.51,163.48,138.28,136.50$, 133.64, 131.72, 129.91, 129.09, 129.09, 110.87, 110.02, 104.28, 78.69, 52.86, 43.63; LCMS (ESI): $m / z$ calculated for $\mathrm{C}_{17} \mathrm{H}_{13} \mathrm{ClO}_{5}$ : 332.73, found: 333.0. Elemental analysis: calculated for $\mathrm{C}_{17} \mathrm{H}_{13} \mathrm{ClO}_{5}$ : C, 61.36, H, 3.93; found: C, 61.30, H, 3.87.

4.3.8 Methyl 2-(4-bromophenyl)-7-hydroxy-4-oxo-3,4-dihydro-2H-chromene-5-carboxylate (5d). Yellow solid (40\%), $R_{\mathrm{f}} 0.67$ (EtOAc/hexane, $3: 7)$; mp: $208{ }^{\circ} \mathrm{C}$; IR $\left(\mathrm{KBr}, \mathrm{cm}^{-1}\right)$ : $3361(\mathrm{OH})$, $1735(\mathrm{C}=\mathrm{O}) ;{ }^{1} \mathrm{H}$ NMR (400 MHz, DMSO-d $\left.{ }_{6}\right): \delta 10.97(\mathrm{~s}, 1 \mathrm{H}, \mathrm{OH})$, $7.60\left(\mathrm{~d}, J=8.8 \mathrm{~Hz}, 2 \mathrm{H}, 3^{\prime}-\mathrm{H}, 5^{\prime}-\mathrm{H}\right), 7.46\left(\mathrm{~d}, J=8.4 \mathrm{~Hz}, 2 \mathrm{H}, 2^{\prime}-\mathrm{H}\right.$, $\left.6^{\prime}-\mathrm{H}\right), 6.44(\mathrm{~s}, 1 \mathrm{H}, 8-\mathrm{H}), 6.41(\mathrm{~s}, 1 \mathrm{H}, 6-\mathrm{H}), 5.62(\mathrm{dd}, J=2.4$, $12.8 \mathrm{~Hz}, 1 \mathrm{H}, 2-\mathrm{H}), 3.74\left(\mathrm{~s}, 3 \mathrm{H}, \mathrm{OCH}_{3}\right), 3.08(\mathrm{q}, J=4.4,12.8 \mathrm{~Hz}$, $1 \mathrm{H}, 3-\mathrm{H}), 2.72$ (dd, $J=2.8,14.4 \mathrm{~Hz}, 1 \mathrm{H}, 3-\mathrm{H}) ;{ }^{13} \mathrm{C}$ NMR (100 MHz, DMSO-d $\left.{ }_{6}\right): \delta 189.05,169.48,164.53,163.46,138.69$, 136.50, 132.01, 132.01, 129.34, 129.34, 122.23, 110.87, 110.03, 104.28, 78.72, 52.86, 43.59; LCMS (ESI): $\mathrm{m} / \mathrm{z}$ calculated for $\mathrm{C}_{17} \mathrm{H}_{13} \mathrm{BrO}_{5}$ : 377.18, found: 377.8. Elemental analysis: calculated for $\mathrm{C}_{17} \mathrm{H}_{13} \mathrm{BrO}_{5}$ : C, 54.13, H, 3.47; found: C, 54.08, H, 3.43.

4.3.9 Methyl 7-hydroxy-2-(4-methylphenyl)-4-oxo-3,4-dihydro-2H-chromene-5-carboxylate (5e). Yellow solid (40\%), $R_{\mathrm{f}} 0.7$ (EtOAc/hexane, 3.5 : 6.5); mp: $198^{\circ} \mathrm{C}$; IR $\left(\mathrm{KBr}, \mathrm{cm}^{-1}\right): 3367(\mathrm{OH})$, $1739(\mathrm{C}=\mathrm{O}) ;{ }^{1} \mathrm{H}$ NMR (400 MHz, DMSO-d $\left.{ }_{6}\right): \delta 10.97(\mathrm{~s}, 1 \mathrm{H}, \mathrm{OH})$, 7.40 (d, $\left.J=8 \mathrm{~Hz}, 2 \mathrm{H}, 2^{\prime}-\mathrm{H}, 6^{\prime}-\mathrm{H}\right), 7.23$ (d, $J=7.6 \mathrm{~Hz}, 2 \mathrm{H}, 3^{\prime}-\mathrm{H}, 5^{\prime}-$ $\mathrm{H}), 6.45(\mathrm{~s}, 1 \mathrm{H}, 8-\mathrm{H}), 6.43(\mathrm{~s}, 1 \mathrm{H}, 6-\mathrm{H}), 5.58(\mathrm{dd}, J=2.4,12.4 \mathrm{~Hz}$, $1 \mathrm{H}, 2-\mathrm{H}), 3.77$ (s, 3H, $\left.\mathrm{OCH}_{3}\right), 3.13$ (q, $\left.J=4.4,12.8 \mathrm{~Hz}, 1 \mathrm{H}, 3-\mathrm{H}\right)$, 2.71 (dd, $J=2.4,14.8 \mathrm{~Hz}, 1 \mathrm{H}, 3-\mathrm{H}), 2.32\left(\mathrm{~s}, 3 \mathrm{H}, \mathrm{CH}_{3}\right) ;{ }^{13} \mathrm{C} \mathrm{NMR}$ (100 MHz, DMSO-d ${ }_{6}$ ): $\delta 189.34,169.48,164.38,163.59,138.39$, 136.42, 136.21, 129.51, 129.51, 127.10, 127.10, 110.84, 109.80, 104.19, 79.30, 52.78, 43.62, 21.24; LCMS (ESI): $m / z$ calculated for $\mathrm{C}_{18} \mathrm{H}_{16} \mathrm{O}_{5}$ : 312.31, found: 313.05 . Elemental analysis: calculated for $\mathrm{C}_{18} \mathrm{H}_{16} \mathrm{O}_{5}$ : C, 69.21, H, 5.15; found: C, 69.27, $\mathrm{H}, 5.21$.

4.3.10 Methyl 2-(2-fluorophenyl)-7-hydroxy-4-oxo-3,4-dihydro- $2 \mathrm{H}$-chromene-5-carboxylate (5f). Yellow solid (40\%), $R_{\mathrm{f}} 0.68$ (EtOAc/hexane, $3: 7)$; mp: $195{ }^{\circ} \mathrm{C}$; IR $\left(\mathrm{KBr}, \mathrm{cm}^{-1}\right)$ : $3461(\mathrm{OH})$, $1735(\mathrm{C}=\mathrm{O}) ;{ }^{1} \mathrm{H}$ NMR (400 MHz, DMSO-d $\left.{ }_{6}\right): \delta 11.03(\mathrm{~s}, 1 \mathrm{H}, \mathrm{OH})$, 7.64-7.68 (m, 1H, 3'-H), 7.45-7.48 (m, 1H, 4'-H), 7.26-7.32 (m, $\left.2 \mathrm{H}, 5^{\prime}-\mathrm{H}, 6^{\prime}-\mathrm{H}\right), 6.46(\mathrm{~s}, 2 \mathrm{H}, 6-\mathrm{H}, 8-\mathrm{H}), 5.85(\mathrm{dd}, J=2.4,13.2 \mathrm{~Hz}$, $1 \mathrm{H}, 2-\mathrm{H}), 3.78\left(\mathrm{~s}, 3 \mathrm{H}, \mathrm{OCH}_{3}\right), 3.23(\mathrm{q}, J=3.2,14 \mathrm{~Hz}, 1 \mathrm{H}, 3-\mathrm{H})$, $2.73(\mathrm{dd}, J=2.4,14 \mathrm{~Hz}, 1 \mathrm{H}, 3-\mathrm{H}) ;{ }^{13} \mathrm{C}$ NMR $\left(100 \mathrm{MHz}, \mathrm{DMSO}_{6}\right)$ : $\delta 188.85,169.40,164.46,163.43,161.32,158.86,136.50,131.40$, 128.97, 125.90, 125.24, 116.32, 110.70, 104.15, 73.95, 52.82, 42.27; LCMS (ESI): $m / z$ calculated for $\mathrm{C}_{17} \mathrm{H}_{13} \mathrm{FO}_{5}$ : 316.28 , found: 317.05. Elemental analysis: calculated for $\mathrm{C}_{17} \mathrm{H}_{13} \mathrm{FO}_{5}$ : C, 64.55, $\mathrm{H}, 4.13$; found: $\mathrm{C}, 64.49, \mathrm{H}, 4.20$.

4.3.11 General procedure for the synthesis of methyl 7hydroxy-2-(substituted phenyl)-4-oxo-4H-chromene-5-carboxylates (6a-f). $\quad \mathrm{I}_{2} \quad(0.15 \mathrm{mmol})$ was added to methyl 7-hydroxy-2(substituted phenyl)-4-oxo-3,4-dihydro-2 $\mathrm{H}$-chromene-5-carboxylates $(5 \mathbf{a}-\mathbf{f})(3 \mathrm{mmol})$ in DMSO $(10 \mathrm{~mL})$, and the mixture was refluxed for $1 \mathrm{~h}$. The progress of the reaction was observed by TLC. After completion, the reaction mixture was cooled to room temperature and quenched with water. The aqueous layer was extracted with ethyl acetate. The organic layer was separated, dried over sodium sulfate and concentrated, and the crude product was obtained, which was purified by column chromatography (hexane-ethyl acetate, $40: 60$ ) to obtain methyl 7-hydroxy-2-(substituted phenyl)-4oxo- $4 H$-chromene-5-carboxylates $6(\mathbf{a}-\mathbf{f})$ in $60 \%$ yield.

4.3.12 Methyl 7-hydroxy-2-(4-methoxyphenyl)-4-oxo-4Hchromene-5-carboxylate (6a). $\mathrm{Mp}: 226-228{ }^{\circ} \mathrm{C}$; IR $\left(\mathrm{KBr}, \mathrm{cm}^{-1}\right)$ : $3446(\mathrm{OH}), 1735(\mathrm{C}=\mathrm{O}), 1624(\mathrm{C}=\mathrm{O}) ;{ }^{1} \mathrm{H}$ NMR $(400 \mathrm{MHz}$, DMSO-d $\left.{ }_{6}\right): \delta 11.14(\mathrm{~s}, 1 \mathrm{H}, \mathrm{OH}), 8.04\left(\mathrm{~d}, J=7.2 \mathrm{~Hz}, 2 \mathrm{H}, 2^{\prime}-\mathrm{H}, 6^{\prime}-\right.$ $\mathrm{H}), 7.12\left(\mathrm{~d}, J=7.2 \mathrm{~Hz}, 2 \mathrm{H}, 3^{\prime}-\mathrm{H}, 5^{\prime}-\mathrm{H}\right), 7.10(\mathrm{~d}, J=2 \mathrm{~Hz}, 1 \mathrm{H}, 6-\mathrm{H})$, $6.82(\mathrm{~d}, J=1.6 \mathrm{~Hz}, 1 \mathrm{H}, 8-\mathrm{H}), 6.79(\mathrm{~s}, 1 \mathrm{H}, 3-\mathrm{H}), 3.86\left(\mathrm{~s}, 3 \mathrm{H}, \mathrm{OCH}_{3}\right)$, 3.81 (s, $\left.3 \mathrm{H}, \mathrm{OCH}_{3}\right) ;{ }^{13} \mathrm{C}$ NMR (100 MHz, DMSO-d $\left.{ }_{6}\right): \delta$ 175.68, 169.19, 162.54, 162.39, 158.55, 157.70, 134.55, 128.59, 127.11, $123.49,114.98,114.81,113.94,113.55,105.58,104.25,55.97$, 52.86; LCMS (ESI): $m / z$ calculated for $\mathrm{C}_{18} \mathrm{H}_{14} \mathrm{O}_{6}: 326.3$, found: 327.0. Elemental analysis: calculated for $\mathrm{C}_{18} \mathrm{H}_{14} \mathrm{O}_{6}: \mathrm{C}, 66.25, \mathrm{H}$, 4.32; found: C, 66.31, H, 4.28 .

4.3.13 Methyl 2-(3,4-dimethoxyphenyl)-7-hydroxy-4-oxo4H-chromene-5-carboxylate (6b). Mp: 233-236 ${ }^{\circ} \mathrm{C}$; $\quad$ IR $\left(\mathrm{KBr}, \mathrm{cm}^{-1}\right)$ : $3444(\mathrm{OH}), 1737(\mathrm{C}=\mathrm{O}), 1627(\mathrm{C}=\mathrm{O}) ;{ }^{1} \mathrm{H}$ NMR (400 MHz, DMSO-d $\left.{ }_{6}\right): \delta 11.08(\mathrm{~s}, 1 \mathrm{H}, \mathrm{OH}), 7.63\left(\mathrm{~d}, J=8 \mathrm{~Hz}, 1 \mathrm{H}, 6^{\prime}-\mathrm{H}\right)$, 7.52 (s, 1H, 2'-H), 7.13 (m, 2H, 5'-H, 6-H), 6.84 (s, 1H, 8-H), 6.79 (s, 1H, 3-H), $3.85\left(\mathrm{~s}, 3 \mathrm{H}, \mathrm{OCH}_{3}\right), 3.81\left(\mathrm{~s}, 3 \mathrm{H}, \mathrm{OCH}_{3}\right), 3.78(\mathrm{~s}, 3 \mathrm{H}$, $\left.\mathrm{OCH}_{3}\right) ;{ }^{13} \mathrm{C}$ NMR $\left(100 \mathrm{MHz}, \mathrm{DMSO}-\mathrm{d}_{6}\right): \delta 175.74,169.19,162.48$, 162.36, 157.74, 152.34, 149.47, 134.51, 123.59, 120.29, 113.53, 113.39, 112.14, 109.83, 105.89, 104.34, 56.32, 56.17, 52.87; LCMS (ESI): $m / z$ calculated for $\mathrm{C}_{19} \mathrm{H}_{16} \mathrm{O}_{7}: 356.32$, found: 357.0. Elemental analysis: calculated for $\mathrm{C}_{19} \mathrm{H}_{16} \mathrm{O}_{7}$ : C, 64.04, H, 4.52; found: C, 64.16, H, 4.59.

4.3.14 Methyl 2-(4-chlorophenyl)-7-hydroxy-4-oxo-4Hchromene-5-carboxylate (6c). Mp: $262-268{ }^{\circ} \mathrm{C}$; IR $\left(\mathrm{KBr}, \mathrm{cm}^{-1}\right)$ : $3645(\mathrm{OH}), 1714(\mathrm{C}=\mathrm{O}), 1697(\mathrm{C}=\mathrm{O}) ;{ }^{1} \mathrm{H}$ NMR $(400 \mathrm{MHz}$, DMSO-d ${ }_{6}$ ): $\delta 11.19(\mathrm{~s}, 1 \mathrm{H}, \mathrm{OH}), 8.07\left(\mathrm{~d}, J=8.8 \mathrm{~Hz}, 2 \mathrm{H}, 3^{\prime}-\mathrm{H}, 5^{\prime}-\right.$ $\mathrm{H}), 7.60\left(\mathrm{~d}, J=8.4 \mathrm{~Hz}, 2 \mathrm{H}, 2^{\prime}-\mathrm{H}, 6^{\prime}-\mathrm{H}\right), 7.08$ (s, 1H, 6-H), 6.89 (s, $1 \mathrm{H}, 8-\mathrm{H}), 6.80$ (s, $1 \mathrm{H}, 3-\mathrm{H}), 3.78\left(\mathrm{~s}, 3 \mathrm{H}, \mathrm{OCH}_{3}\right) ;{ }^{13} \mathrm{C}$ NMR $(100$ MHz, DMSO-d $\left.{ }_{6}\right): \delta 175.75,169.06,162.63,161.24,157.79$, 136.99 , 134.60, 130.28, 129.62, 129.62, 128.60, 128.60, 113.86, 113.36, 107.48, 104.32, 52.91; LCMS (ESI): $m / z$ calculated for $\mathrm{C}_{17} \mathrm{H}_{11} \mathrm{ClO}_{5}$ : 330.71, found 331.0. Elemental analysis: calculated for $\mathrm{C}_{17} \mathrm{H}_{11} \mathrm{ClO}_{5}$ : C, 61.73, H, 3.34; found: $\mathrm{C}, 61.67, \mathrm{H}, 3.28$.

4.3.15 Methyl 2-(4-bromophenyl)-7-hydroxy-4-oxo-4Hchromene-5-carboxylate (6d). Mp: $275-277 \quad{ }^{\circ} \mathrm{C}$; $\quad$ IR $\left(\mathrm{KBr}, \mathrm{cm}^{-1}\right)$ : $3564(\mathrm{OH}), 1737(\mathrm{C}=\mathrm{O}), 1627(\mathrm{C}=\mathrm{O}) ;{ }^{1} \mathrm{H}$ NMR (400 MHz, DMSO-d $\left.{ }_{6}\right): \delta 11.18(\mathrm{~s}, 1 \mathrm{H}, \mathrm{OH}), 8.0\left(\mathrm{~d}, J=8 \mathrm{~Hz}, 2 \mathrm{H}, 3^{\prime}-\mathrm{H}\right.$, $\left.5^{\prime}-\mathrm{H}\right), 7.75$ (d, $\left.J=8 \mathrm{~Hz}, 2 \mathrm{H}, 2^{\prime}-\mathrm{H}, 6^{\prime}-\mathrm{H}\right), 7.07$ (s, 1H, 3-H), $6.90(\mathrm{~s}$, $1 \mathrm{H}, 6-\mathrm{H}), 6.81(\mathrm{~s}, 1 \mathrm{H}, 8-\mathrm{H}), 3.78\left(\mathrm{~s}, 3 \mathrm{H}, \mathrm{OCH}_{3}\right) ;{ }^{13} \mathrm{C}$ NMR $(100$ MHz, DMSO-d $\left.\mathrm{d}_{6}\right): \delta 175.90,169.90,162.70,161.52,157.84$, 134.62, 132.62, 132.62, 130.59, 128.76, 128.76, 126.01, 113.93, 113.35, 107.41, 104.38, 53.03; LCMS (ESI): $m / z$ calculated for $\mathrm{C}_{17} \mathrm{H}_{11} \mathrm{BrO}_{5}$ : 375.17, found: 376.9, 378.9. Elemental analysis: calculated for $\mathrm{C}_{17} \mathrm{H}_{11} \mathrm{BrO}_{5}$ : C, 54.42, $\mathrm{H}, 2.95$; found: $\mathrm{C}, 54.48, \mathrm{H}$, 2.95 .

4.3.16 Methyl 7-hydroxy-2-(4-methylphenyl)-4-oxo-4Hchromene-5-carboxylate (6e). Mp: $240-242{ }^{\circ} \mathrm{C}$; IR $\left(\mathrm{KBr}, \mathrm{cm}^{-1}\right)$ : $3516(\mathrm{OH}), 1737(\mathrm{C}=\mathrm{O}), 1627(\mathrm{C}=\mathrm{O}) ;{ }^{1} \mathrm{H}$ NMR $(400 \mathrm{MHz}$, DMSO-d 6 ): $\delta 11.18(\mathrm{~s}, 1 \mathrm{H}, \mathrm{OH}), 7.95\left(\mathrm{~d}, J=8.0 \mathrm{~Hz}, 2 \mathrm{H}, 2^{\prime}-\mathrm{H}, 6^{\prime}-\right.$ $\mathrm{H}), 7.38\left(\mathrm{~d}, J=8.0 \mathrm{~Hz}, 2 \mathrm{H}, 3^{\prime}-\mathrm{H}, 5^{\prime}-\mathrm{H}\right), 7.10(\mathrm{~s}, 1 \mathrm{H}, 6-\mathrm{H}), 6.84$ $(\mathrm{s}, 1 \mathrm{H}, 8-\mathrm{H}), 6.83(\mathrm{~s}, 1 \mathrm{H}, 3-\mathrm{H}), 3.81\left(\mathrm{~s}, 3 \mathrm{H}, \mathrm{OCH}_{3}\right), 2.39(\mathrm{~s}, 3 \mathrm{H}$, $\left.\mathrm{CH}_{3}\right) ;{ }^{13} \mathrm{C}$ NMR (100 MHz, DMSO-d $\left.{ }_{6}\right): \delta$ 175.76, 169.14, $162.49,157.78,142.42$, 134.58, 130.25, 130.14, 130.14, 128.55, 
126.68, 126.68, 113.68, 113.43, 106.46, 104.27, 52.88, 21.51; LCMS (ESI): $m / z$ calculated for $\mathrm{C}_{18} \mathrm{H}_{14} \mathrm{O}_{5}: 310.3$, found: 311.0 . Elemental analysis: calculated for $\mathrm{C}_{18} \mathrm{H}_{14} \mathrm{O}_{5}$ : C, 69.66, $\mathrm{H}$, 4.54; found: C, 69.61, H, 4.49.

4.3.17 Methyl 2-(2-fluorophenyl)-7-hydroxy-4-oxo-4Hchromene-5-carboxylate (6f). $\mathrm{Mp}$ : $222-225{ }^{\circ} \mathrm{C}$; IR $\left(\mathrm{KBr}, \mathrm{cm}^{-1}\right)$ : $3645(\mathrm{OH}), 1732(\mathrm{C}=\mathrm{O}), 1697(\mathrm{C}=\mathrm{O}) ;{ }^{1} \mathrm{H}$ NMR $(400 \mathrm{MHz}$, DMSO-d $\left.{ }_{6}\right): \delta 11.22(\mathrm{~s}, 1 \mathrm{H}, \mathrm{OH}), 8.02-8.06\left(\mathrm{~m}, 1 \mathrm{H}, 3^{\prime}-\mathrm{H}\right), 7.63-$ $7.70\left(\mathrm{~m}, 1 \mathrm{H}, 4^{\prime}-\mathrm{H}\right), 7.41-7.5\left(\mathrm{~m}, 2 \mathrm{H}, 5^{\prime}-\mathrm{H}, 6^{\prime}-\mathrm{H}\right), 7.06(\mathrm{~s}, 1 \mathrm{H}, 6-\mathrm{H})$, 6.86 (s, 1H, 8-H), 6.65 (s, 1H, 3-H), $3.81\left(\mathrm{~s}, 3 \mathrm{H}, \mathrm{OCH}_{3}\right) ;{ }^{13} \mathrm{C} \mathrm{NMR}$ (100 MHz, DMSO-d $\mathrm{d}_{6}$ ): $\delta$ 185.83, 169.39, 164.45, 163.43, 161.07, 159.11, 136.50, 131.36, 128.96, 128.93, 125.21, 116.30, 116.12, 110.71, 110.07, 104.15, 52.81; LCMS (ESI): $\mathrm{m} / \mathrm{z}$ calculated for $\mathrm{C}_{17} \mathrm{H}_{11} \mathrm{FO}_{5}: 314.26$, found: 315.0. Elemental analysis: calculated for $\mathrm{C}_{17} \mathrm{H}_{11} \mathrm{FO}_{5}$ : C, 64.96, H, 3.52; found: C, 64.91, H, 3.56.

\section{Biological activity}

All the chemicals used for the activity study were procured from Sigma-Aldrich, USA.

\subsection{Evaluation of in vitro antimycobacterial activity}

5.1.1 Cultivation of mycobacteria. The Mycobacterium tuberculosis H37Ra (ATCC 25177) strain was obtained from AstraZeneca, India. The stock culture was maintained at $-80{ }^{\circ} \mathrm{C}$ and subcultured once in liquid $M$. phlei medium, which contained $0.5 \mathrm{~g} \mathrm{KH}_{2} \mathrm{PO}_{4}, 0.25 \mathrm{~g}$ trisodium citrate, $60 \mathrm{mg} \mathrm{MgSO}_{4}$, $0.5 \mathrm{~g}$ asparagine and $2 \mathrm{~mL}$ glycerol in distilled water $(100 \mathrm{~mL})$, followed by adjustment of the $\mathrm{pH}$ to 6.6 . Stock cultures of bacilli were first grown in $M$. phlei medium at $37{ }^{\circ} \mathrm{C}$ at $150 \mathrm{rpm}$ for at least 8-10 days before an OD of 1 at $620 \mathrm{~nm}$ was recorded.

5.1.2 Antitubercular activity. Stock solutions $\left(10 \mathrm{mg} \mathrm{mL}^{-1}\right)$ of all the newly synthesized compounds were prepared in DMSO and were evaluated for their in vitro antitubercular activity against $M$. tuberculosis H37Ra (ATCC 25177) in a liquid medium using an established XTT reduction menadione assay (XRMA) method. ${ }^{22}$ In brief, $2.5 \mu \mathrm{L}$ of a test solution $\left(30-0 \mu \mathrm{g} \mathrm{mL}{ }^{-1}\right)$ was added to $248.5 \mu \mathrm{L}$ of $M$. phlei medium containing bacilli and incubated at $37^{\circ} \mathrm{C}$ for 8 days. Post-incubation, the XRMA was carried out to estimate the number of viable cells present in different wells of the assay plate. The absorbance was recorded with a microplate reader (SpectraMax Plus 384, Molecular Devices, Inc.) using a $470 \mathrm{~nm}$ filter against a blank prepared from cell-free wells. The absorbance displayed by cells treated with the vehicle alone was taken as representing $100 \%$ cell growth. The MIC and $\mathrm{IC}_{50}$ values of the compounds were calculated using Origin 6 software. The percentage inhibition was calculated using the following equation: percentage inhibition $=[$ (absorbance of control - absorbance of test sample $) /$ (absorbance of control - absorbance of blank)] $\times 100$, where control denotes the medium with bacilli together with the vehicle and blank denotes the cell-free medium. A drug in clinical use, namely, isoniazid, was used as a reference.

5.1.3 Antibacterial activity. To investigate the specificity of the synthesised derivatives $\mathbf{5 a}-\mathbf{f}$ and $\mathbf{6 a - f}$, all the compounds were screened for their antibacterial activity in 96-well plates against four bacterial strains (Gram-negative strains: Escherichia coli (NCIM 2065; ATCC 8739) and Pseudomonas aeruginosa (NCIM 5029; ATCC 27853); Gram-positive strains: Staphylococcus aureus (NCIM 2901; ATCC 29737) and Bacillus subtilis (NCIM 2920; ATCC 6051)). All four strains were grown in LuriaBertani medium from HiMedia, India. Once the culture reached an $\mathrm{OD}_{620}$ of 1 , it was used to test antibacterial activity. Bacterial cultures with an $\mathrm{OD}_{620}$ of 0.1 were treated with the synthesized compounds at different concentrations $\left(30,10\right.$, and $\left.3 \mu \mathrm{g} \mathrm{mL} L^{-1}\right)$ and incubated for $8 \mathrm{~h}$ at $37^{\circ} \mathrm{C}$. The post-incubation $\mathrm{OD}_{620}$ was measured for both Gram-positive and Gram-negative bacteria.

\section{Conflicts of interest}

There is no conflict of interest among the authors.

\section{Acknowledgements}

The authors are thankful to the Director, Agharkar Research Institute and the Director, National Chemical Laboratory, Pune, India for providing infrastructure and financial support. Sagar Swami (File no: 31/011(0983)2017/EMR-01) is grateful to the Council of Scientific \& Industrial Research (CSIR), New Delhi, India for the award of a Junior Research Fellowship (JRF). Amit Choudhari (File No: PDF/2016/003615) is grateful to the Science and Engineering Research Board (SERB), Government of India, New Delhi for the award of a National Post-Doctoral Fellowship.

\section{References}

1 World Health Organization WHO http://apps.who.int/iris/ handle/10665/254762.

2 World Health Organization WHO http://www.who.int/ mediacentre/factsheets/fs104/en/.

3 H. Marrakchi, G. Lanéelle and A. Quémard, Microbiology, 2000, 146, 289-296.

4 H. Marrakchi, S. Ducasse, G. Labesse, H. Montrozier, E. Margeat, L. Emorine, et al., Microbiology, 2002, 148, 951960.

5 A. Quemard, J. C. Sacchettini, A. Dessen, C. Vilcheze, R. Bittman, W. R. Jacobs, et al., Biochemistry, 1995, 34, 8235-8241.

6 S. Ducasse-Cabanot, M. Cohen-Gonsaud, H. Marrakchi, M. Nguyen, D. Zerbib, J. Bernadou, et al., Antimicrob. Agents Chemother., 2004, 48, 242-249.

7 C. Bjorkelid, T. Bergfors, A. K. Raichurkar, K. Mukherjee, K. Malolanarasimhan, B. Bandodkar, et al., J. Biol. Chem., 2013, 288, 18260-18270.

8 M. M. Johnson and J. A. Odell, J. Thorac. Dis., 2014, 6, 210220.

9 Q. F. Hu, B. Zhou, J. M. Huang, Z. Y. Jiang, X. Z. Huang, L. Y. Yang, X. M. Gao, G. Y. Yang and C. T. Che, J. Nat. Prod., 2013, 76, 1866-1871.

10 N. V. Puranik and P. Srivastava, RSC Adv., 2017, 7, 3305233060 . 
11 S. A. Villaume, J. Fu, I. N'Go, H. Liang, H. Lou, L. Kremer, W. Pan and S. P. Vincent, Chem.-Eur. J., 2017, 23, 1042310429.

12 G. Poncet-Montange, S. Ducasse-Cabanot, A. Quemard, G. Labesse and M. Cohen-Gonsaud, Acta Crystallogr., Sect. D: Biol. Crystallogr., 2007, 63, 923-925.

13 B. Chetnani, S. Das, P. Kumar, A. Surolia and M. Vijayan, Acta Crystallogr., Sect. D: Biol. Crystallogr., 2009, 65, 312-325.

14 M. O. Kim, S. E. Nichols, Y. Wang and J. A. McCammon, J. Comput.-Aided Mol. Des., 2013, 27, 235-246.

15 R. A. Friesner, J. L. Banks, R. B. Murphy, T. A. Halgren, J. J. Klicic, D. T. Mainz, M. P. Repasky, E. H. Knoll, M. Shelley and J. K. Perry, J. Med. Chem., 2004, 47, 17391749.
16 R. A. Friesner, R. B. Murphy, M. P. Repasky, L. L. Frye, J. R. Greenwood, T. A. Halgren, P. C. Sanschagrin and D. T. Mainz, J. Med. Chem., 2006, 49, 6177-6196.

17 W. L. Jorgensen, D. S. Maxwell and J. Tirado Rives, J. Am. Chem. Soc., 1996, 118, 11225-11236.

18 J. McNulty and D. Mcleod, Tetrahedron Lett., 2013, 54, 63036306.

19 J. Maresh, J. Zhang, Y. L. Tzeng, N. A. Goodman and D. G. Lynn, Bioorg. Med. Chem. Lett., 2007, 17, 3281-3286.

20 J. Johann, PCT Int. Appl., 2010, 2010022953.

21 M. M. Naik, S. G. Tilve and V. P. Kamat, Tetrahedron Lett., 2014, 55, 3340-3343.

22 U. Singh, S. Akhtar, A. Mishra and D. Sarkar, J. Microbiol. Methods, 2011, 84, 202. 